\title{
The
}

University

of Chicago

Law Review

VOLUME 51 NUMBER 1 WINTER 1984

- 1984 by The University of Chicago

\section{Simplifying Retained Life Interests, Revocable Transfers, and the Marital Deduction}

\section{Joseph Isenbergh $\dagger$}

Sections 2036, 2037, and 2038 of the Internal Revenue Code ${ }^{1}$ contain several long-standing rules of estate taxation designed to preserve the taxable estate from erosion. Section 2036(a)(1) pulls back into the taxable estate the value of property transferred before death subject to a retained life interest, thus exposing to taxation interests in property that would otherwise expire with the decedent. ${ }^{2}$ The apparent theory of this rule is that one who has enjoyed property for life and has controlled its subsequent disposition ought to be treated at death as its owner. Section 2037 returns to the estate transfers taking effect at death in which the decedent had a reversionary interest. ${ }^{3}$ Sections 2036(a)(2) and 2038 reach transfers subject to revocation, amendment, or other control by the transferor. ${ }^{4}$

The taxable estate is further protected by sections 2056 (b) and 2523(b), which deny the marital deduction ${ }^{5}$ for transfers between

$\dagger$ Professor of Law, University of Chicago. Research for this article was supported by a grant from the Russell Baker Scholars Fund.

1 I.R.C. $\$ \S 2036-2038$ (1982).

s See I.R.C. § 2036(a)(1) (1982).

s See I.R.C. \& 2037 (1982).

- See I.R.C. \$§ 2036(a)(2), 2038 (1982).

- A transfer tax deduction is normally allowed for transfers to a spouse under I.R.C. $\S$ 2056(a), 2523(a) (1982). 
spouses of life interests or other "terminable" interests in property.$^{6}$ While this rule is similar in effect to the rules on retained life interests, the theory behind it is more complex. It appears aimed at preserving the taxable estate from erosion and at imposing a tax cost on the exercise of dead hand control over transfers to a surviving spouse. ${ }^{7}$

This article reviews the background and operation of these rules. Though justified under earlier forms of the transfer tax laws, they are now little more than sources of unnecessary complexity and could therefore be repealed without creating substantial new possibilities of tax avoidance. In addition, to offset the greater attractiveness of certain lifetime gifts that might result, the transfer tax base should be enlarged to include in the estate all gift taxes paid during life. An additional effect of these changes would be a sounder, although more severe, transfer tax treatment of interestfree loans. The following discussion develops, through a series of examples, the underlying relations that support this position. ${ }^{8}$

\section{Retained Life INTERests}

\section{A. World Without Gift Tax}

In a world with an estate tax but no gift tax, ${ }^{9}$ outright gifts of property between generations could be used to avoid all transfer taxes. Even so, for a number of sound reasons (among them the fate of King Lear), ${ }^{10}$ few people would be prepared to give away all their property during life. If, however, the estate tax reached only property actually owned by a decedent at the time of death, ${ }^{11}$ transfers of future interests in property coupled with retained life

- See I.R.C. $\$ \S 2056(b), 2523(b)$ (1982).

Tee infra notes $92-94$ and accompanying text.

For the sake of simplicity I have rounded the figures in my discussion of the examples.

The world was essentially so between 1916 and 1932. The Revenue Act of 1916, Pub. L. No. 64-271, 39 Stat. 756, imposed no gift tax. A gift tax law with almost no teeth was enacted in 1924, Revenue Act of 1924, Pub. L. No. 68-176, §§ 319-324, 43 Stat. 253, 313-16, but was repealed by the Revenue Act of 1926, Pub. L. No. 69-20, tit. XII, $\$ 1200,44$ Stat. (pt. 2) 9, 126. The first effective gift tax was imposed by the Revenue Act of 1932, Pub. L. No. 72-154, tit. III, $\S \S 501-532,47$ Stat. 169, 245-59. The current gift tax statute is codified at I.R.C. $\S \S 2501-2524$ (1982).

${ }_{10}$ As the Fool says to Lear in act I, scene 4 of William Shakespeare's King Lear, shortly after Lear has made a present gift of his kingdom to two of his daughters: "thou mad'st thy daughters thy mothers."

${ }^{11}$ This is the present sweep of I.R.C. $\S 2033$ (1982), which provides that "[t]he value of the gross estate shall include the value of all property to the extent of the interest therein of the decedent at the time of his death." 
interests would allow the transfer of wealth from one generation to the next free of tax and without the hazards of self-destitution. To illustrate:

\section{Example 1}

-Estate tax at a flat rate of $10 \%$

-Property subject to a retained life interest is not included in taxable estate

You own $\$ 5$ million. You can, of course, avoid all transfer taxes simply by giving the $\$ 5$ million to your heirs, but hesitate to do so.

If you are satisfied to live from the income of your $\$ 5$ million, you can also transfer a future interest in the $\$ 5$ million to your heirs (typically through a trust) and retain the income for yourself for life. In this tax system there is a present transfer of the remainder (a transfer itself not taxed, because there is no gift tax), but there is no taxable transfer at your death because the life interest will expire with you and you will therefore own no property at death. The full $\$ 5$ million will therefore pass to your heirs free of tax. By contrast, if you choose to live on the income from your fortune and leave the $\$ 5$ million outright at your death, $\$ 500,000$ of estate tax will then be payable.

A rule governing transfers subject to retained life interests is necessary to cut off the possibility suggested in this example. Not surprisingly, the original 1916 estate tax law provided, in a predecessor provision to section 2036(a)(1), ${ }^{12}$ that the taxable estate would include property " $[t] 0$ the extent of any interest therein of which the decedent has at any time made a transfer . . . intended

12 I.R.C. $\$ 2036(a)(1)$ (1982) states the present rule governing retained life interests. The text of I.R.C. $\S 2036$ (a) reads in relevant part:

(a) General Rule

The value of the gross estate shall include the value of all property to the extent of any interest therein of which the decedent has at any time made a transfer . . . by trust or otherwise, under which he has retained for his life or for any period not ascertainable without reference to his death or for any period which does not in fact end before his death-

(1) the possession or enjoyment of, or the right to the income from, the property, or

(2) the right, either alone or in conjunction with any person, to designate the persons who shall possess or enjoy the property or the income therefrom. 
to take effect in possession or enjoyment at or after his death ."13 Applied to Example 1, this rule would, it seems, pull the full $\$ 5$ million back into the taxable estate upon the transferor's death. $^{14}$

\section{B. World With Gift Tax}

1. Taxes at Flat Rates-Gift Tax Lower. Suppose now that there is a flat rate gift tax, which for historical reasons we shall set at three-quarters of the estate tax rate. ${ }^{15}$ With a gift tax in place, the next examples must make assumptions about life expectancy and the time value of money.

\section{Example 2}

—Gift tax rate: $7.5 \%$

-Estate tax rate: $10 \%$

-Life expectancy: 20 years

-Property subject to a rêtained life interest is not included in taxable estate

-Discount rate: $10 \%$

You own $\$ 5$ million. A transfer of a remainder interest in $\$ 5$ million to your heirs, with income retained for life, is a taxable gift

23 Revenue Act of 1916, Pub. L. No. 64-271, tit. II, § 202(b), 39 Stat. 756, 777-78 (current version at I.R.C. $\$ 2036(a)$ (1) (1982)).

14 Amazingly enough, in May v. Heiner, 281 U.S. 238 (1930), the Supreme Court held that the language of $\S 202$ (b) did not apply to the pattern of Example 1 because it only applied to transfers where actual title (as opposed to some nontitular beneficial interest) passed at death. 281 U.S. at 243-45. May $v$. Heiner was actually decided under $\S 402$ (c) of the Revenue Act of 1918, Pub. L. No. 65-254, tit. IV, $\S 402$ (c), 40 Stat. 1057, 1097 (current version at I.R.C. $\S 2036$ (a)(1) (1982)), which carried forward the language of $\S 202$ (b) of the Revenue Act of 1916, Pub. L. No. 64-271, tit. II, § 202(b), 39 Stat. 756, 777-74 (current verison at I.R.C. $\$ 2036(\mathrm{a})(1)(1982)$ ). In cases where, under local property law, legal title to property (in Example 1, the $\$ 5$ million) passed during life, there was nothing to tax at death. It turned out, therefore, that between 1916 and 1931 the trust arrangement described in Example 1 would successfully have avoided all transfer taxes. In 1949 the Supreme Court repented of its earlier view and overruled May v. Heiner in Commissioner v. Estate of Church, 335 U.S. 632, 637 (1949). By then the issue was comparatively unimportant; in 1932, Congress had enacted a more explicit rule covering all forms of retained life interests. See Revenue Act of 1932, Pub. L. No. 72-154, tit. VI, \& 803(a), 47 Stat. 169, 279 (current version at I.R.C. 2036(a)(1) (1982)).

16 This three-to-four relationship between the gift tax rates and the estate tax rates was in effect from 1932, the year of the first effective gift tax, until 1976. See Revenue Act of 1932, Pub. L. No. 72-154, tit. II, $\S 401$ (b), 47 Stat. 169, 243 (estate tax rate schedule beginning at $1 \%$ on net estates not in excess of $\$ 10,000$ ); id. tit. III, $\S 502,47$ Stat. at 246 (gift tax rate schedule beginning at three-quarters of $1 \%$ on net gifts not in excess of $\$ 10,000)$. In 1976 gift and estate tax rates were unified in a single schedule, see Tax Reform Act of 1976, Pub. L. No. 94-455, tit. XX, \& 2001(a)(1), 90 Stat. 1520, 1846-48 (codified as amended at I.R.C. \& 2001 (1982)). 
(even though of a future interest). ${ }^{18}$ This remainder must therefore be valued for gift tax purposes. Assuming a life expectancy of 20 years and a discount rate of $10 \%$, the $\$ 5$ million remainder is worth $\$ 750,000$, and is therefore a present gift of that amount. ${ }^{17}$ At the $7.5 \%$ tax rate, there is a gift tax of $\$ 56,250$. Because we have assumed that the expiration of the life interest will not be a taxable event, there will be no further tax at death.

Instead of making a gift now you can simply await events and live off the income from the $\$ 5$ million. If you do in fact live the scheduled twenty years, there will be an estate tax of $\$ 500,000$ in year 20.

In the simplified world of Example 2, there is a choice between paying $\$ 56,250$ now or $\$ 500,000$ in 20 years (on average). ${ }^{18}$ Discounted to present value (still at $10 \%$ ), the $\$ 500,000$ payment in 20 years is equivalent to a present payment of $\$ 75,000$. Even after discounting, holding the entire property until death entails (on average) a higher transfer tax cost than transferring a remainder now and retaining a life interest. The present tax saving from the latter procedure is $\$ 18,750$.

In Example 2 there remains a tax advantage from a transfer of a remainder subject to a retained life interest, but much reduced compared with Example 1-even in the absence of any rule bringing the remainder back into the taxable estate-because of the gift tax cost of present transfers of future interests. The tax saving from using a remainder with a retained life interest results from the different rates of tax imposed on lifetime gifts and transfers at death. What would otherwise be a future transfer (taxable at death) has been converted and discounted to a present transfer (taxable at lower gift tax rates). The present tax cost of the transfer taxed as a gift is three-quarters of the present tax cost of keeping the entire property until death-precisely the ratio of the gift

16 The gift tax reaches all transfers made during life, in whatever form, valued as of the time of the transfer. See I.R.C. $\$ \S 2501(\mathrm{a})(1), 2511(\mathrm{a}), 2512(\mathrm{a})$ (1982). The transfer of a future interest is thus taxable when made at its discounted value.

17 The choice of a discount rate is necessarily somewhat arbitrary. Ten percent, besides being a reasonable reflection of current financial conditions and expectations, has the virtue of arithmetic simplicity. The IRS, moveover, has recently proposed newly-drawn valuation tables for annuities and terminable interests that use a $10 \%$ discount rate. See Revision of Actuarial Tables and Interest Factors, 48 Fed. Reg. 50,087, 50,108-11 (1983) (to be codified at 26 C.F.R. $\S 25.2512-5$ ) (proposed Oct. 25, 1983). Though final adoption of the rule is pending, it became effective on an interim basis on Dec. 1, 1983. See id. at 50,087.

18 These examples ignore the effect of the removal of the $\$ 56,250$ from the estate tax base, a factor discussed in some detail infra notes $29-33,57-58$ and accompanying text. 
tax to the estate tax in this example. ${ }^{10}$ The tax saving from the lifetime transfer simply reflects the different rates of tax imposed on gifts and transfers at death. If the gift tax were at the same $10 \%$ rate as the estate tax, the tax saving from the lifetime transfer would disappear.

If gift tax rates and estate tax rates were flat and identical, there would be no tax advantage (assuming proper valuations and no differences between the estate tax and gift tax bases) ${ }^{20}$ to the transfer of remainders with retained life interests, even without any special rule governing this pattern. ${ }^{21}$ Of course, Example 2 simplifies reality; it takes into account neither the effects of graduation in tax rates nor the differences between the tax base for gifts and that for transfers at death. ${ }^{22}$ Until 1976, the gift tax was imposed on a separate tax base at graduated rates lower than those imposed on estates. ${ }^{23}$ Transfers of remainders subject to retained life interests could therefore offer, besides the advantage already illustrated of converting a future transfer to one taxed currently under a more favorable rate schedule, the additional possibility of pulling part of the estate into the lower reaches of the gift tax brackets in order to create two separate trips through graduated transfer tax brackets. ${ }^{24}$ As the following examples will show, however, the transfer tax structure and rates introduced in 1976 and 1981 narrowed somewhat the range of what could be accomplished through the use of remainders with retained life interests.

2. The 1976 Changes. In 1976 , a "unified" rate schedule was made applicable to the sum of lifetime gifts and transfers at death. ${ }^{25}$ Although this change did not remove the entire potential

19 See supra note 15 and accompanying text.

${ }^{20}$ See infra notes 29-33 and accompanying text for a discussion of the differences between the estate tax and gift tax bases.

21 There might even be a disadvantage in transferring a remainder if the discount rate applied in valuing the remainder were too low compared with the rate appropriate to measure the time value of the tax payment itself. Under these circumstances, the transfer of a remainder would trigger a present tax more costly in present terms than the tax payable at death. Until very recently, the IRS's own valuation tables, which used a low discount rate of $6 \%$, see Treas. Reg. § 25.2512-9 (1970), could easily yield this result. However, newly-drawn valuation tables, recently proposed by the IRS, use a $10 \%$ discount rate. See Revision of Actuarial Tables and Interest Factors, 48 Fed. Reg. 50,087, 50,108-11 (1983) (to be codified at 26 C.F.R. $\$ 25.2512-5$ ) (proposed Oct. 25, 1983). The final adoption of these newly-drawn tables would somewhat reduce this disadvantage in transferring a remainder.

22 See infra notes 29-33 and accompanying text.

${ }^{23}$ See supra note 15.

24 Differences in the tax base between lifetime gifts and transfers at death can have the same effect as differences in tax rates. See infra notes 29-33 and accompanying text.

2s See Tax Reform Act of 1976, Pub. L. No. 94-455, tit. XX, § 2001(a)(1), 90 Stat. 1520, 
tax advantage of retained life interests, it did strip them of some of their charm, even assuming a Code without the rule of section 2036(a)(1). ${ }^{26}$ Indeed, Congress could quite reasonably have considered eliminating that rule in 1976. To demonstrate these consequences of the 1976 changes, let us work through some examples of retained life interests under the rate structure in effect in 1981, which reflected the full extent of the 1976 changes but not those made in $1981 .^{27}$

\section{Example 3}

-1981 gift and estate tax rates

-Life expectancy: 7 years

-Property subject to a retained life interest not included in taxable estate

-Discount rate: $10 \%$

In this example you own $\$ 6$ million. You are old, and your life expectancy is only 7 years. If you simply do nothing, choosing to live off the income of your fortune, you will leave an estate of $\$ 6$ million in year 7 , which will attract a tax of $\$ 3.2$ million. Discounted at $10 \%$, this course entails a present tax cost of roughly $\$ 1.6$ million.

Suppose instead that you transfer a remainder interest in $\$ 5$ million to your heirs, retaining the income for life. Given your life expectancy (7 years), this remainder interest of $\$ 5$ million is worth $\$ 2.5$ million today (discounted at $10 \%$ ). You have made a present gift of $\$ 2.5$ million. This transfer results in a gift tax of roughly $\$ 1$ million, which you can pay because you have set aside $\$ 1$ million from the transfer you made. You are left with a life interest in $\$ 5$ million. At your death (because we are in a world without section 2036) there is no further tax. This plan therefore entails a total present tax cost of $\$ 1$ million, the amount paid on the taxable gift. Compared with the equivalent testamentary transfer there is a present tax saving of $\$ 600,000$.

The source of the tax advantage offered by the transfer of a

1846-48 (codified as amended at I.R.C. \& 2001 (1982)).

28 See supra text accompanying note 2 .

27 See infra notes 45-63 and accompanying text for a discussion of the treatment of retained life interests following the changes in the law instituted by the Economic Recovery Tax Act of 1981, Pub. L. No. 97-34, tit. IV, $\$ \S 402-442,95$ Stat. 172, 299-323 (codified in scattered sections of I.R.C. (1982)). 
remainder is twofold. First, there is a "bracket effect." The present gift of a remainder (a future interest) makes use of the lower graduated brackets. When the remainder is valued by being discounted back to the present, there is a foreshortening of its future nominal value (of $\$ 5$ million) to a present value of $\$ 2.5$ million. These two values are equivalent in present terms, but the taxes on the future and the present amounts are not. The future tax on the high bracket portion of the future transfer (i.e., the amount above $\$ 2.5$ million) is itself not discounted back to present value to determine the present tax. Rather, a present tax is determined based on lower bracket amounts. The bracket increase resulting from the nominal increase in value of the remainder over 7 years has thus been avoided. The result, in effect, is a form of bracket splitting with one's own estate. The component of the overall $\$ 600,000$ tax. savings attributable to this "bracket effect" is roughly $\$ 250,000 .{ }^{28}$

Second, there is a "tax base" effect. Under present law, the gift tax and the estate tax are each imposed on a different tax base. The amount of a taxable gift does not include the gift tax itself, which is paid by the donor as a percentage of the net amount received by the donee. ${ }^{29}$ By contrast, the estate tax base does include the estate tax: the tax comes out of the amount of the taxable estate itself. ${ }^{30}$ The exclusion of the gift tax from the gift tax base means that gifts are taxed at a lower effective rate, despite the "unified" rate schedule for gifts and transfers at death adopted in 1976. Although this discrepancy was partly remedied by section 2035 (c), added to the Code in $1976,{ }^{31}$ gifts made more than

${ }^{28}$ At 1981 rates, a transfer of $\$ 2.5$ million is taxed at an effective rate of approximately $40 \%$ (marginal rate of $53 \%$ ) while a $\$ 5$ million transfer is taxed at an effective rate of approximately $50 \%$ (marginal rate of 70\%). See I.R.C. $\$ 2001$ (c) (1976) (amended 1981). The conversion of a transfer of $\$ 5$ million in 7 years to one of $\$ 2.5$ million today therefore entails a future tax greater by $\$ 500,000$ than if the effective rate of $40 \%$ were applicable to both transfers. Assuming the extra $\$ 500,000$ were payable in year 7 , the tax saving attributable to the "bracket effect" in year 0 , using a $10 \%$ discount rate, is $\$ 250,000$.

29 See I.R.C \$§ 2502(c) (1982) (gift tax to be paid by donor), 2503(a) (1982) (taxable gifts defined as "total amount of gifts made during the calendar year" less charitable gifts and gifts to a spouse).

so I.R.C. § 2053(c)(1)(B) (1982) provides that "any estate, succession, legacy, or inheritance taxes, shall not be deductible" for purposes of calculating the taxable estate. A similar pattern governs the taxation of income, where the amount of the tax itself is not deductible in computing taxable income. See id. $\$ 164$ (1982) (specifying the taxes that are deductible for purposes of calculating taxable income).

s1 I.R.C. § 2035(c) (1982) was enacted as part of the Tax Reform Act of 1976, Pub. L. No. $94-455$, tit. XX, $\S 2001$ (a)(5), 90 Stat. 1520, 1848-49. I.R.C. $\$ 2035$ (c) provides that the gross estate "shall be increased by the amount of any [gift] tax paid ... by the decedent .. . during the 3-year period ending on the date of the decedent's death." 
three years before death continue to be taxed at a lower effective rate because of the tax base effect.

In Example 3, the gift of a $\$ 5$ million remainder creates a present tax obligation of $\$ 1$ million. This $\$ 1$ million of tax is removed from the estate when paid and will itself not be subject to taxation at death. At the highest marginal rate for $1981(70 \%)^{32}$ this $\$ 1$ million, if retained in the estate until death, would attract an additional tax at death of $\$ 700,000$. If payable on average in year 7 , this $\$ 700,000$ is the equivalent of $\$ 350,000$ in year 0 . This $\$ 350,000$ makes up the balance of the $\$ 600,000$ difference in tax cost between the testamentary gift and the remainder with a retained life estate in Example 3.

A tax saving of $\$ 600,000$ on a $\$ 6$ million estate is substantial. Indeed, if the comparison were limited to the options available in Example 3, the rule of section 2036(a)(1)-which prevents this tax saving by including in the estate the amount of any lifetime gift subject to a retained life interest ${ }^{3 s}$-might seem justified. To the extent, however, that transfers of wealth other than those illustrated in Example 3 can produce advantages similar to those of the gift of a remainder without running afoul of section 2036(a)(1), the rule it codifies merely creates a pitfall around which the knowing can channel their exercise of generosity.

In Example 3 the donor was satisfied with an income stream during life equal to the income from his capital. Another way of producing comparable cash flows is the purchase of an annuity of an appropriate amount, a transaction that falls outside the reach of section $2036(a)(1) . .^{34}$

32 See I.R.C. § 2001(c) (1976) (amended 1981).

33 I.R.C. $\$ 2036(a)(1)$ (1982), quoted supra note 12, taxes the retained-life-interest pattern of Example 3 as follows. The gift tax consequences of the transfer of a $\$ 5$ million remainder are unchanged (approximately $\$ 1$ million of tax at 1981 rates). Section 2036(a) pulls the entire $\$ 5$ million remainder back into the taxable estate, which will entail an additional $\$ 1.5$ million of tax at death (a tax of $\$ 2.5$ million on $\$ 5$ million, minus the $\$ 1$ million of tax previously paid). The tax cost in year 0 of the retained life interest is thus $\$ 1.75$ million ( $\$ 1$ million of gift tax payable now, plus the present cost of $\$ 1.5$ million payable in 7 years, which is $\$ 750,000$ ). This is $\$ 150,000$ more than the simple plan of doing nothing.

36 An annuity is not a retained life interest, but represents a combination of income and return of capital. An interest in property exchanged for an annuity is fully converted to a different form. 


\section{Example 4}

-Retained life interests pulled back into estate under section 2036

-1981 gift and estate tax rates

-Life expectancy: 7 years

-Discount rate: $10 \%$

Mindful of potential tax base and bracket effects, you can make an outright gift of $\$ 2.5$ million to your heirs and pay a present gift tax of $\$ 1$ million. If you live at least three more years, the amount of the gift tax is removed from the estate. ${ }^{35}$ With the remaining $\$ \mathbf{2 . 5}$ million, you can provide for yourself by buying an annuity. For a life expectancy of 7 years, and with a rate of return on the annuity of $10 \%$, the annual annuity payment would be $\$ 500,000$, which is the same amount yielded by a retained life interest of $\$ 5$ million at $10 \% .{ }^{36}$ of course, a commercial annuity company may not give this rate of return, especially to a self-selected individual buyer. There remains, however, the possibility of purchasing a private annuity from your heirs who, having among other things just received a gift of $\$ 2.5$ million, may well be able to afford to enter into such a transaction with you. Your heirs now have $\$ 5$ million, but must make payments to you until your death.

The predicted tax cost of the plan outlined in this example is $\$ 1$ million. The present gift of $\$ 2.5$ million attracts a tax of $\$ 1$ million. If the entire proceeds of the annuity are consumed during life, there will be no further transfer tax at death. The overall tax consequences of this plan are therefore the same as in the remainderwith-life-interest pattern of Example 3.37

35 See supra note 31 and accompanying text.

36 Both the annuity and the life interest are streams of equal annual payments (assuming constant interest rates) whose present value is equal to $\$ 5$ million less the value of the remainder, or $\$ 2.5$ million.

${ }^{37}$ When a private annuity is used, the rate of return has a different effect. The lower the rate of return, the greater the size of the fund transferred to the heirs. The greater also are the income-splitting possibilities for income tax purposes: if the return from the fund given over to the heirs is greater than the internal rate of return on the private annuity, the actual return is in effect being split between two taxpayers for income tax purposes. Until recently, the IRS's own regulations set $6 \%$ as the required discount rate for the valuation of annuities for transfer tax purposes. See Treas. Reg. \& 25.2512-9 (1970). While the IRS insisted on a discount rate of $6 \%$ in valuing income streams in order to tax them, it could not easily attack the same rate of return when used in private annuities. These income-splitting opportunities will be somewhat curtailed, however, should the IRS adopt recently proposed valuation tables using a $10 \%$ discount rate. See Revision of Actuarial Tables and Interest 
As between generations, especially when a private annuity is used, the result in this example is similar to the result achieved by using a remainder with a retained life interest. If the annuitant dies prematurely the heirs gain unencumbered ownership of the fund sooner than anticipated, much as they would were they remaindermen of a life estate. If, on the other hand, the annuitant outlives his life expectancy, the heirs remain obliged to pay him $\$ 500,000$ each year, which is in effect the same result as if a life interest had been retained..$^{38}$

A combination of present gifts and annuity arrangements can thus generate the same tax base and bracket effects as the use of retained life interests. ${ }^{30}$ To be sure, the present-gift-plus-annuity pattern is not identical to a retained life interest, but it achieves similar nontax ends. ${ }^{40}$

Furthermore, the potential advantage of using retained life interests over simply holding property is probably less in any event than appeared in Example 3. In that example, the same discount rate $(10 \%)$ was used to value transfers taking effect in the future and to measure the time value of the tax deferral itself. In measuring the value of deferring tax, however, a higher discount rate may be appropriate. There is less certainty that a tax, once deferred, will be paid at all than there is that dollars committed in trust to a remainder interest will be available in the future. A present tax, once paid during life, is gone. The needs of the transferring generation may change, however, because of illness or remarriage for example, and its members may want to consume more during life. In that event, part of any transfer taxes paid early could end up having been paid unnecessarily, because the amounts ultimately transferred between generations would turn out to be smaller than originally anticipated.

A second element of uncertainty favoring deferral is the possi-

Factors, 48 Fed. Reg. 50,087, 50,108-11 (1983) (to be codified at 26 C.F.R. $\$ 25.2512-5$ ) (proposed Oct. 25, 1983). The proposed tables became effective on an interim basis on Dec. 1 , 1983. See id. at 50,087 .

${ }^{38}$ In both cases the heirs enjoy the full economic benefit of the fund only after the transferor's death.

39 The bracket effect here results from making a present gift equivalent in value to a future transfer of twice the number of dollars. See supra note 28 and accompanying text.

40 The income tax consequences of the gift-plus-annuity arrangement may be different from those of the retained-life-interest pattern, although not necessarily less favorable. For a discussion of the opportunities for income-splitting afforded by a gift-plus-annuity arrangement, see supra note 37. See also Sackett, Using Private Annuities Today: The Benefits, The Drawbacks, and Open Questions, $49 \mathrm{~J}$. TAx'N 48 (1978) (discussing the consequences of using the private annuity as a means of transferring property). 
bility of changes in the transfer tax laws themselves. ${ }^{41}$ To take an example based on recent experience, if the retained life interest of Example 3 had been created in February, 1981, the advantage would have proved much smaller in light of the tax rates now scheduled to be in effect after $1986 .{ }^{42}$ Using a discount rate of $15 \%$ (rather than 10\%) to value the deferral of tax in Example 3 should the gift be made in testamentary form, the tax advantage of the retained life interest in present terms would be reduced from $\$ 600,000$ to $\$ 200,000$. If $20 \%$ were used, the testamentary gift would actually yield a better result for the taxpayer. ${ }^{43}$

Given that the tax advantage of using retained life interests may be overstated, and given the possibility of using other, albeit more cumbersome, arrangements to achieve the result prevented by section $2036(a)(1)$, the tax burden imposed by that section on retained life interests ${ }^{44}$ functions as little more than a trap for the unwary. Under the structure of transfer taxation put in place by the 1976 changes, it is hard to see why we should want to penalize a device that, tax concerns aside, will sometimes prove a useful way of disposing of wealth among generations.

3. The 1981 Changes. Setting aside for the moment the marital deduction, ${ }^{45}$ the 1981 changes in transfer taxation ${ }^{46}$-consisting largely of rate reductions-are structurally less momentous than those of 1976 . When the new rates are fully in place in 1987, the

4 Abstractly, it may not be valid to analyze a tax system on the assumption that it may be changed, since the object of the analysis is to arrive at a tax system that can be put into place permanently. It is also true that tax rates may go up, a factor that would tend to lower the discount rate applicable to tax deferrals. Nonetheless, few estate planners nowadays would ignore the present drift of feeling against transfer taxes in deciding between present or future tax payments.

42 The rates to be in effect after 1986 are specified in I.R.C. $\$ \S 2001(b)-(c), 2010(a)(6)$ (1982). Keeping all else constant, the tax saving from the retained life interest is $\$ 292,000$ as of 1981 (instead of $\$ 600,000$ as in Example 3). $\$ 250,000$ is attributable to the tax base effect $(50 \% \times \$ 500,000$ ( $\$ 1$ million discounted at $10 \%$ from year 7 to year 0$)=\$ 250,000)$, and the remaining $\$ 42,000$ to the bracket effect (the $\$ 84,000$ difference between the tax on $\$ 5$ million at the 1981 and 1988 effective rates, discounted at $10 \%$ back to 1981 ).

4s The tax of $\$ 3.2$ million payable in year 7 entails a present cost of roughly $\$ 1.2$ million at $15 \%$. At $20 \%$ the present cost is $\$ 900,000$. Note that in these comparisons a discount rate of $10 \%$ is still used to value the present transfer of the $\$ 5$ million remainder, which is proper for the purpose of comparing the value of a dollar in the future with a dollar today. The higher rate applied to the tax deferral reflects the comparatively greater uncertainty that a dollar of tax deferred will ever have to be paid at all.

4t See supra note 33 and accompanying text.

15 For a discussion of the marital deduction, see infra notes 80-115 and accompanying text.

46 The 1981 changes were instituted by the Economic Recovery Tax Act of 1981, Pub. L. No. 97-34, tit. IV, $\S 401-442$, 95 Stat. 172, 299-323 (codified in scattered sections of I.R.C. (1982)). 
highest tax rate on transfers will be $50 \%$, and the unified credit will be $\$ 192,800$ (equivalent to the exemption from tax of transfers up to $\$ 600,000) .^{47}$

The 1981 changes do not much affect the analysis of retained life interests. Overall, the potential advantages of this device are blunted, and the incidence of these advantages is also somewhat different. The $\$ 192,800$ unified credit effectively creates a zerobracket amount of $\$ 600,000$, with a sharp increase in rates (to $37 \%$ ) for the first dollar above that amount. ${ }^{48}$ The bracket effect can therefore be quite notable for future transfers reducible to a present value within the limits of this exemption equivalent. ${ }^{49} \mathrm{Be}$ cause there is only one set of lower brackets, however, the bracket effect is limited, and can never produce, at 1987 tax rates, a tax difference of more than about $\$ 420,000$, no matter how large the estate or the transfers made during life. ${ }^{50} \mathrm{As}$ a practical matter, the bracket effect will almost invariably be much smaller. ${ }^{51}$ Similarly, the decrease in the highest marginal rate from $70 \%$ to $50 \%$ makes the tax base effect of lifetime transfers somewhat smaller, though it remains significant.

Returning to our $\$ 6$ million estate, 1987 rates give the following result. The present tax advantage of a retained life interest-absent the rule of section 2036(a)(1), of course-over a testamentary gift in Example 3 is reduced to $\$ 440,000$, of which

47 See I.R.C. $\S \S 2001(\mathrm{~b})-(\mathrm{c}), 2010(\mathrm{a})-(\mathrm{b})(1982)$.

4 See I.R.C. $\$ 2001$ (c) (1982).

40 Consider, for example, an estate of $\$ 2.4$ million, owned by someone with a life expectancy of 14 years who intends to consume only the income during life. Leaving an estate of $\$ 2.4$ million in 14 years will entail a tax of roughly $\$ 785,000$ at that time. The present cost of this tax, discounted at $10 \%$, is roughly $\$ 200,000$. A present gift of $\$ 600,000$, however, (equal in value, at $10 \%$, to a transfer of $\$ 2.4$ million in 14 years) can be made today without tax, and the remaining $\$ 1.8$ million used to provide for lifetime needs (through an annuity, for example). If the full amount is in fact consumed, there is no tax at death, the entire tax savings $(\$ 200,000)$ deriving from the bracket effect.

so Transfers above $\$ 2.5$ million are taxed at the maximum marginal rate of $50 \%$. Assuming no reduction in rates for lower brackets (i.e. a flat $50 \%$ rate at all levels), the tax on a $\$ 2.5$ million transfer would be $\$ 1.25$ million. The actual tax on a $\$ 2.5$ million transfer (taking into account the unified credit) is roughly $\$ 830,000$. Since the greatest amount of tax that a transfer valued at $\$ 2.5$ million could attract at the maximum marginal rate is $\$ 1.25$ million, the greatest possible tax saving from the foreshortening of the brackets by reducing large future transfers to present value is $\$ 420,000$ (i.e., the difference between $\$ 1.25$ million and $\$ 830,000$ ).

s1 The $\$ 420,000$ figure is a theoretical maximum, which can arise only if death follows immediately upon the transfer of a remainder. The greater the time between these events, the smaller the tax savings from the bracket effect. If, as proposed infra note 61 and accompanying text, the rule were adopted, that transfers of remainder interests during the last three years of life would not be discounted at all, the greatest possible present tax savings from the bracket effect (assuming a $10 \%$ discount rate) would be $\$ 315,000$. 
$\$ 215,000$ is attributable to the tax base effect and $\$ 225,000$ to the bracket effect. $^{62}$ With section $2036(a)(1)$ in effect, the present tax cost of retaining a life interest is $\$ 200,000$ more than simply making a testamentary gift. ${ }^{.3}$ Once again, a combination of present gifts and annuities can achieve a similar result without a transfer tax penalty. ${ }^{54}$

Repeal of section 2036(a)(1), by putting the remainder with retained life interest on the same footing as more cumbersome alternatives, would end this disparity of treatment between similar transfers of wealth. Moreover, the repeal of section 2036(a)(1), even in the absence of other statutory change, would not make the use of retained life interests an automatic choice for taxpayers. The earlier payment of tax would continue to be a potentially costly step, ${ }^{\mathrm{ss}}$ and the reluctance of many to surrender full ownership of their wealth during life would probably not give way to pure tax considerations, especially if these were less than compelling. ${ }^{56}$

If, in addition to the repeal of section 2036(a)(1), the statute were amended to blunt the tax base effect, the tax treatment of retained life interests would be brought more nearly into parity with that of transfers at death. A simple change toward this end, which meshes easily with the repeal of section 2036 (a)(1), would be the inclusion of all gift taxes paid during life in the taxable estate. Section 2035(c) already requires such inclusion (or "gross-up") for

82 If the testamentary gift option is followed, the tax at death (in year 7) will be roughly $\$ 2.6$ million, equivalent to a present tax cost of roughly $\$ 1.3$ million. If a remainder of $\$ 5.1$ million is transferred (present value: $\$ 2.55$ million), with retained life interest, the present tax is approximately $\$ 860,000$.

${ }^{53}$ Assuming section 2036(a)(1) pulls the amount subject to the life estate back into the taxable estate, we still have a present gift of $\$ 2.55$ million, which means a present tax of $\$ 860,000$; but, in addition, $\$ 5.1$ million will be pulled back into the estate at death leading to a future tax of $\$ 2.325$ million reduced, however, by the $\$ 860,000$ payable during life. The amount of tax actually owed at death will therefore be $\$ 1.27$ million (i.e. $\$ 2.325$ million minus $\$ 860,000$ minus the $\$ 192,800$ credit). The present tax cost of the retained life estate would therefore be the $\$ 860,000$ payable immediately plus the present value of $\$ 1.3$ million payable in seven years, or $\$ 650,000$ for a total of roughly $\$ 1.5$ million. The use of the retained life estate therefore entails a greater present tax cost of $\$ 200,000$.

s4 See supra notes 34-40 and accompanying text.

ss See supra notes $41-43$ and accompanying text.

ss Furthermore, the IRS's own tables valuing remainder interests assume life expectancies much shorter than those presently prevailing for the general population, and hence overestimate the present value of remainder interests. See Sackett, supra note 40, at 50 . This fact by itself cuts against transfers of future interests since it reduces the potential foreshortening of the graduated tax brackets that results from reducing future transfers to present value. See supra note 28 and accompanying text. 
gift taxes paid on transfers within three years of death. ${ }^{57} \mathrm{~A}$ small change in the language of section 2035(c) would extend this rule to all transfers made during life. ${ }^{58}$

The bracket effect would not be reduced under this regime. While this effect can be considerable in some cases, it is in all events limited, ${ }^{58}$ and can never loom large in the transfer of dynastic fortunes. As applied to the $\$ 6$ million estate of Example 4, such a tax regime would, at 1987 rates, result in a present tax cost of approximately $\$ 1.1$ million for a retained life interest, or $\$ 200,000$ less than if everything were kept until death. ${ }^{60}$

Repeal of section 2036(a)(1) and the inclusion of gift taxes paid in the estate, without more, would still leave the problem of "deathbed" transfers. Someone in declining health might transfer remainder interests shortly before death. If these were valued on the assumption of a normal life expectancy (known to the grantor to be unlikely), substantial transfer tax savings could result under the tax regime proposed here. One possible countermeasure would be to value transfers made in the last three years of life as though life expectancy at the time of transfer were zero. ${ }^{61}$ Remaining possibilities for manipulation would be slight.

Broader problems of valuation and enforcement could also result from the tax regime proposed here. For example, it might be tempting to transfer future interests during life at highly under-

${ }^{82}$ See I.R.C. $\S 2035$ (c) (1982), quoted in relevant part supra note 31.

ss It would be sufficient to delete the last thirteen words of I.R.C. $\$ 2035$ (c) (1982): "and during the 3-year period ending on the date of the decedent's death."

so supra notes 48-51 and accompanying text for a discussion of the limits on the bracket effect.

- A present transfer of a remainder interest in $\$ 4.5$ million would entail a tax of roughly $\$ 715,000$. This $\$ 715,000$ of tax would be pulled back into the gross estate along with the roughly $\$ 785,000$ remaining, leaving an estate of $\$ 1.5$ million in year 7 . When added to lifetime transfers, this $\$ 1.5$ million estate would attract tax at roughly a $50 \%$ rate, for a total tax at death of $\$ 750,000$, or a present tax cost of $\$ 375,000$. The total present tax cost is therefore $\$ 1,090,000$. The total present tax cost of leaving the entire amount by devise would be $\$ 1.3$ million. See supra note 52 . (The reader will note that this analysis assumes that the entire income from the $\$ 785,000$ retained by the transferor is consumed during life. If the transferor saves the income from the amount not committed to a retained life interest, a remainder interest in $\$ 4.8$ million could be created, at a total present tax cost of roughly $\$ 1,190,000)$.

The remaining $\$ 200,000$ difference in tax cost reflects the bracket advantage of reducing future transfers to present values. With the repeal of section $2036(\mathrm{a})$, the bracket effect from retained life interests would be irreducible, unless graduated transfer tax rates were abandoned altogether.

61 This countermeasure would cause remainders subject to retained life interests transferred during the 3-year period to be included in the unified tax base of I.R.C. $\$ 2001$ (1982) without discount. The transfer of tax consequences would therefore be the same as if the entire amount had remained in the estate at death. 
stated values. The present rule of section 2036(a)(1) "polices" such maneuvers by requiring that the property transferred subject to a retained life interest be included in the taxable estate at its value at the time of death. Without such a rule, the IRS could end up with only one chance-i.e., the lifetime transfer itself-to tax the transfer between generations at an appropriate level.

This potential abuse is simply an aspect of the ubiquitous and largely irreducible problem of valuation of lifetime transfers, an area where taxpayers often have the upper hand. ${ }^{.2}$ One possible controlling measure would be to require the executor to report in the estate tax return all the transfers of future interests made by the decedent during life. The IRS then could seek adjusted gift taxes for the prior years, if transfers have been either undervalued or omitted altogether. ${ }^{63}$ Such a reporting requirement entails no greater administrative difficulties than the present system, under which the executor must also identify and report lifetime transfers of future interests in order to give effect to section 2036(a)(1).

\section{Revocable and Other Transfers}

Once gift taxes paid during life are added to the taxable estate, the present statutory treatment of reversions and revocable interests also becomes largely unnecessary. Section 2037 of the Code pulls back into the estate transfers taking effect at death in which the transferor retains a reversionary interest worth more than $5 \%$ of the value of the property transferred..$^{64}$ Sections $2038^{65}$

62 Taxpayers have the upper hand in such matters of valuation because they can (and do) make transfers of property the value of which may depend on subsequent events within their control or even on their own efforts. The transfer of shares of stock of a company that the transferor intends to manage actively for only modest compensation is such a case. Similar is the transfer of land the future value (but not the present value) of which may reflect the cost of substantial expenses for development or mineral exploration subsequently to be made on contiguous land retained by the transferor. It is quite difficult for the transfer tax system to deal with this problem. See, e.g., Commissioner v. Hogle, 165 F.2d 352, 353 (10th Cir. 1947) (transfer of wealth resulting from performance of beneficial services held not a taxable transfer).

es Some modification of the statute of limitations for gift taxes might be necessary. Under present law, there is no limitation period unless a gift tax return has been filed, and there is a 10-year limitation on assessments resulting from gross undervaluation of gifts. A simple solution would be to allow gift tax for any lifetime transfer to be assessed through the end of the limitation period for the estate tax. It is entirely reasonable, in a system of purportedly unified transfer taxes on lifetime gifts and transfers at death, to keep the possibility of taxation open on all transfers until final settlement of the estate tax. The whole point of the unified tax base and rate structure is that transfer taxation is not a once-a-year matter, but a once-a-lifetime matter.

4 The text of I.R.C. $\S 2037$ (1982) reads in relevant part:

(a) General Rule- 
and $2036(a)(2)^{66}$ reach transfers subject to revocation, amendment, or other means of control by the transferor. The overall effect of these rules is that any number of strings or powers can tie property to the estate even though that property was ostensibly transferred during life.

These provisions of the Code have long and complex histories and their existence largely reflects the absence of any gift tax in the early period of transfer taxes. ${ }^{67}$ The Treasury did not want transfers made during life treated as completed gifts and argued strenuously, and successfully in early cases, that revocable or other similar transfers had no transfer tax consequences during life. ${ }^{68}$ As a corollary, such transfers had to be included in the taxable estate at death.

If lifetime gifts are taxed at essentially the same rates as transfers at death, ${ }^{89}$ taxpayers gain from the deferral of tax on revocable transfers. There is no reason why all transfers of beneficial interests in property including revocable gifts should not be taxed since a revocable gift certainly confers the benefit of the time value of the gift until revocation on its recipient. Exactly how much of a benefit depends on the intention of the grantor. This uncertainty, however, goes to the value of the gift, not to the existence of a gift in the first place. Since the maker of a revocable gift has the key to its value in his own hands, it is entirely reasonable to resolve any

The value of the gross estate shall include the value of all property to the extent of any interest therein of which the decedent has at any time after September 7, 1916, made a transfer . . . by trust or otherwise, if-

(1) possession or enjoyment of the property can, through ownership of such interest, be obtained only by surviving the decedent, and

(2) the decedent has retained a reversionary interest in the property . . . and the value of such reversionary interest immediately before the death of the decedent exceeds 5 percent of the value of such property.

os The text of I.R.C. $\S 2038$ (1982) reads in relevant part:

(a) In General

The value of the gross estate shall include the value of all property-

(1) Transfers after June 22, 1936-

To the extent of any interest therein of which the decedent has at any time made a transfer . . . by trust or otherwise, where the enjoyment thereof was subject at the date of his death to any change through the exercise of a power . . . by the decedent . . . to alter, amend, revoke, or terminate, or where any such power is relinquished during the 3 year period ending on the date of the decedent's death.

es For the relevant part of the text of I.R.C. § 2036(a)(2) (1982), see supra note 12.

-7 For a review of gift tax laws since 1916, see supra note 9 .

6s See, e.g., Burnet v. Guggenheim, 288 U.S. 280, 288 (1933) (revocable transfer held not a currently taxable gift).

co See supra notes 15,25 and accompanying text. 
uncertainties of valuation against the grantor and to tax revocable and amendable gifts during life at the same value they would have if made unconditionally. ${ }^{70}$

This change would bear significantly on the tax regime applicable to interest-free demand loans. Under present law, an interest-free demand loan, being essentially a revocable transfer of funds, attracts no transfer tax when it is made. ${ }^{71}$ The lender's periodic forebearance to receive interest enriches the borrower at the lender's expense and is, by virtue of the recently decided case of Dickman v. Commissioner, ${ }^{72}$ treated as a current taxable gift. ${ }^{73}$

If, as proposed here, revocable transfers were presently taxable, then the full face amount of interest-free demand loans would attract gift tax. ${ }^{74}$ This is an entirely plausible result where the lender has in fact no intention of calling the loan, and has therefore transferred more than the time value of the money. If an arm's length interest rate were charged, however, the obligation to pay interest would offset the value of the transfer. ${ }^{75}$ Loans at bargain interest rates would be taxable transfers measured by the

70 The principle of valuation underlying this proposal has been widely accepted. See Robinette v. Commissioner, 318 U.S. 184, 188-89 (1943); Lockard v. Commissioner, 166 F.2d 409, 414 (1st Cir. 1948) (both stating that grantor must bear the burden for transfer tax purposes of the impossibility of valuing reversionary right).

"1 See I.R.C. § 2038 (1982), quoted in relevant part supra note 65.

73104 S. Ct. 1086, 1091-92 (1984). Before Dickman, in a widely cited case, Crown v. Commissioner, 585 F.2d 234 (7th Cir. 1978), one court concluded that a taxable gift resulted neither from the initial grant of an interest-free loan nor from the annual failure of the lender to collect interest. Id. at 237-39; accord Johnson v. United States, 254 F. Supp. 73, 77 (N.D. Tex 1966). The lower court in Dickman had taken a different view. Dickman v. Commissioner, 690 F.2d 812, 819 (11th Cir. 1982) (interest-free demand loan held to give rise to periodic taxable gifts).

73 Interest-free loans also frequently produce income tax benefits from the effective assignment of the income on the borrowed funds from the lender to the borrower. If the borrower is in a lower income tax bracket (or derives untaxed imputed income from the use of the funds, as will result, for example, from the purchase of a house) this income-splitting will be advantageous. Under several decided cases, interest-free loans are not questioned as income-splitting devices; by contrast, explicit Code provisions tax income from a revocable trust to the grantor. Compare Dean v. Commissioner, 35 T.C. 1083, 1087-90 (1961) (treatment of interest-free loans), with I.R.C. $\$ \$ 671-679$ (1982) (treatment of "grantor" trusts).

34 Measures to mitigate the harshness of such a rule in the case of intra-family loans made without interest in emergencies or by inadvertance might be desirable. First, a safeharbor exception could be established for loans that are in fact soon repaid (e.g., within 6 months) and not renewed. Second, the opportunity to "cure" the interest-free character of certain loans by paying an appropriate amount of interest retrospectively could also be allowed.

${ }^{78}$ This treatment would permit a program of periodic gifts to be made by means of a demand loan. Forgiveness of the interest obligation by the lender as it arose would give rise to successive gifts. Cf. Haygood v. Commissioner, 42 T.C. 936, 946-47 (1964) (annual forgiveness of installment sale payments gives rise to periodic taxable gifts). 
value of the bargain element. ${ }^{76}$

These changes would create significant transfer tax consequences for some widely used will substitutes, although perhaps less than first appears. The device most likely to be affected is the revocable transfer of a remainder interest, which would be taxed when made in the same manner as its irrevocable cousin. ${ }^{77}$ Used principally until now to avoid probate, these transfers could take on an additional attraction from the lower effective transfer tax rates on lifetime gifts resulting from the tax base effect. Here again, however, this advantage would be significantly blunted by the inclusion of the amount of the gift tax in the taxable estate.

In sum, if the full range of transfers now reached by sections 2036(a)(2) and 2038 were taxed when made under a unified rate schedule, there would be little reason to include them in the taxable estate. Inclusion of previously paid gift taxes in the taxable estate $^{78}$ is a sufficient step toward unified rates to permit the transfer tax system to proceed happily without the complexities of sections 2036(a)(2), 2037, and 2038.78

\section{Marital Deduction for Terminable Interests}

\section{A. The Basic Pattern}

A deduction for transfers between spouses was introduced in 1948 , ostensibly to equalize the transfer tax treatment of married couples in common law states and community property states. ${ }^{80} \mathrm{In}$

36 Cf. Estate of Berkman v. Commissioner, 38 TAx CT. MeM. Dec. (CCH) 183 (Jan. 31, 1979); Blackburn v. Commissioner, 20 T.C. 204 (1953) (both adopting such valuation of bargain term loans). The simplest way to measure the bargain element is to multiply the principal amount of the loan by the ratio of (1) the difference between the arm's length interest and the bargain rate, over (2) the arm's length rate. Thus a $4 \%$ loan made at a time when the arm's length rate was $10 \%$ would be a gift of $6 / 10$ ths of the principal amount.

${ }^{72} \mathrm{By}$ contrast, revocable transfers of present interests (in the form of demand loans and others) are probably best thought of as "gift substitutes," in that they shift the present enjoyment of property without (under current law) transfer tax cost.

${ }_{78}$ For discussion of the proposal to include all previously paid gift taxes in the transfer tax base, see supra notes 57-58 and accompanying text.

70 To make the proposal outlined in this section unequivocally effective, it might be necessary as a technical matter, in addition to repealing these various estate tax provisions, to provide under the gift tax that taxable transfers include the full amount of revocable, amendable, or reversionary transfers, without diminution on account of the powers or reversions to which the transfer is subject. In both Robinette v. Commissioner, 318 U.S. 184, 188 (1943) and Lockard v. Commissioner, 166 F.2d 409, 413-14 (1st Cir. 1948), the taxpayers argued, albeit unsuccessfully, that the value of the transfer should be reduced for purposes of calculating the gift tax by the value of the reversion held by the grantor. The additional provision suggested in this footnote would specifically foreclose such a line of argument.

${ }^{\text {so }}$ See Revenue Act of 1948, Pub. L. No. 80-471, tit. III, § 361(a), 62 Stat. 110, 117-21 
its original form, the marital deduction was limited to one-half the adjusted gross estate. ${ }^{81}$ After several intervening changes, an unlimited marital deduction, both for gifts and transfers at death, now codified in sections 2523 and 2056 of the Code, was introduced in the Economic Recovery Tax Act of $1981 .^{82}$ As a general proposition, transfers between spouses now pass free of tax. ${ }^{83}$ The result is not, however, a total forgiveness of tax, but rather a deferral of tax on transferred amounts that remain within the same generation. Upon the death of the surviving spouse, a transfer tax will ultimately be imposed if the remaining estate is large enough. ${ }^{84}$

From the beginning there have been restrictions on the marital deduction, the most notable being the denial of the deduction for "terminable" interests in property now codified in section 2056(b). ${ }^{85}$ With some exceptions, no marital deduction is allowed for interests in property transferred to a surviving spouse if the interest may terminate or fail in favor of another person. The most obvious examples of such terminable interests are a life estate or an interest for a term of years to the surviving spouse with remainder to another. In general, the existence of another person with a succeeding interest in the property is essential to the definition of "terminable" interests. ${ }^{86}$ Interests in property that terminate sim-

(current version at I.R.C. $\$ \S 2056,2523$ (1982)).

81 See id. § 361, 62 Stat. at 117-21 (current version at I.R.C. $\S \S 2056,2523$ (1982)).

82 See Economic Recovery Tax Act of 1981, Pub. L. No. 97-34, tit. IV, § 403(d)(1)-(2), 95 Stat. 172, 302-03 (codified at I.R.C. §§ 2056, 2523 (1982)).

${ }^{83}$ See I.R.C. \$ 2056(a) (1982).

s6 The size of the estate remaining upon the death of the surviving spouse is a relevant consideration because the unified transfer tax credit, which will be fully available in 1987 under I.R.C. \& 2010(a)-(b) (1982), effectively exempts estates up to $\$ 600,000$ from tax. See supra note 47 and accompanying text.

ss I.R.C. § 2056(b) (1982), reads in relevant part:

(b) Limitation in the case of life estate or other terminable interest-

(1) General Rule-

Where, on the lapse of time, on the occurrence of an event or contingency, or on the failure of an event or contingency to occur, an interest passing to the surviving spouse will terminate or fail, no [\$ 2056(a) marital] deduction shall be allowed with respect to such interest-

(A) if an interest in such property passes ... to any person other than such surviving spouse ...; ; and

(B) if by reason of such passing such person . . . may possess or enjoy any part of such property after such termination or failure of the interest so passing to the surviving spouse;

and no deduction shall be allowed with respect to such interest (even if such deduction is not disallowed under subparagraphs (A) and (B)) -

(C) if such interest is to be acquired for the surviving spouse, pursuant to directions of the decedent, by his executor or by the trustee of a trust. 
ply by virtue of being wasting assets are not necessarily terminable interests within the meaning of the statute. A patent, the survivor's portion of a purchased annuity, or even an automobile, are bound to terminate, but no other person necessarily takes upon the termination of these interests. They simply disappear. Such interests are not treated as "terminable" under the Code, and can therefore qualify for the marital deduction..$^{87}$

There is, however, a further complication: the marital deduction is denied, even for "wasting" terminable interests, if the interest is actually acquired for the surviving spouse by the executor pursuant to directions of the decedent. ${ }^{88}$ So, for example, though a marital deduction is available for the transfer of a patent or annuity at death, it is not available if the executor is specifically instructed in the decedent's will to acquire a patent or annuity for the surviving spouse.

Several explanations of the rule on terminable interests have been offered, but the most plausible is that it prevents the deferral of tax inherent in the marital deduction from becoming total forgiveness. An analysis of the following example illustrates the various possibilities for tax deferral:

\section{Example 5}

-1987 rates

-Husband $(H)$ owns $\$ 2.4$ million

-Wife $(W)$ owns no property

$-W$ stands on average to outlive $H$ by 14 years

$-H$ and $W$ have one child $(C)$

-Discount rate: $10 \%$

By virtue of the marital deduction, $H$ can transfer the $\$ 2.4$ million to $W$ at death free of tax. If $W$ is satisfied to live on the income from this fund for the rest of her life, she will leave $\$ 2.4$ millon to $C$ at her own death. Her estate will owe roughly $\$ 800,000$ of tax, payable on average fourteen years after $H$ 's death. ${ }^{89}$ Discounted at $10 \%$, the tax cost of this plan (as of $H$ 's death) is therefore roughly $\$ 200,000$.

87 See id.

see I.R.C. § 2056(b)(1)(C) (1982).

sP It seems reasonable to estimate that $W$ will live for another 14 years given that women have a longer life expectancy than men and that in the usual marriage the wife is several years younger than the husband. For purposes of arithmetical calculations, moreover, it is convenient to use a multiple of seven, since at a $10 \%$ discount rate, money roughly doubles every seven years. 
If there were no limitation on the marital deduction for terminable interests, $H$ could do better. If the income from $\$ 2.4$ million suffices for $W$ 's needs, $H$ could leave $W$ a life interest in $\$ 2.4$ million with remainder to $C$. The life interest transferred to $W$, given her life expectancy, would be worth $\$ 1.8$ million (assuming a $10 \%$ rate of interest). If the marital deduction could be claimed for the value of this transfer, a $\$ 600,000$ taxable estate (the present value of the remainder over to $C$ ) would remain at $H$ 's death, an amount equal to the exemption equivalent. ${ }^{90}$ The expiration of $W$ 's life estate at her own death would not itself be a taxable event, and no further tax would be incurred. Thus, in a world in which terminable interests qualified for the marital deduction, wealth could be distributed with the same effect as in Example 5 at no tax cost. Under present law, however, the general rule of section 2056(b) would cut off the marital deduction in this instance, and a tax of $\$ 800,000$ on the full $\$ 2.4$ million estate would be payable immediately upon $H$ 's death - a result far worse than the $\$ 200,000$ tax cost of Example 5.

\section{B. Powers of Appointment and "Qualified" Terminable Interests}

One could conclude from the analysis of Example 5 that the rule on terminable interests exists to guarantee inclusion of property in the estate of at least one spouse. This conclusion is bolstered by section $2056(b)(5),{ }^{91}$ which allows the marital deduction for the entire value of transferred property in which the surviving spouse has a terminable interest if the surviving spouse also holds a broad power of appointment over the underlying property. The section also allows the deduction for the value of a "specific portion" of the property if the life interest and power of appointment extend only to that portion. Because property subject to such a power of appointment will subsequently be included in the estate of the surviving spouse, taxation at least once in the spouses' generation is assured. In effect, this provision treats the surviving spouse as having full beneficial ownership of property subject to a

so See supra notes 47,84 and accompanying text.

81 I.R.C. $\$ 2056(b)(5)$ (1982), the text of which reads in relevant part:

(5) Life estate with power of appointment in surviving spouse-

In the case of an interest in property passing from the decedent, if his surviving spouse is entitled to all the income from the entire interest, or all the income from a specific portion thereof . . . with power in the surviving spouse to appoint the interest, or such specific portion...

(A) the interest or such portion thereof so passing shall . . . be considered as passing to the surviving spouse.... 
broad power.

There is more, however, to the rule on terminable interests than the wish to tax the property at least once in the spouses' generation. In Example 5, $W$ was prepared to live on the income from $\$ 2.4$ million $(\$ 240,000$ per year at $10 \%)$. Someone with a life expectancy of 14 years can acquire such an income stream for an investment of less than $\$ 2.4$ million by purchasing an annuity. At a $10 \%$ rate of return such a $\$ 240,000$ annuity should cost $\$ 1.8$ million. The possibility of using an annuity suggests the following arrangement. $H$ transfers $\$ 600,000$ outright to $C$ at death, and the balance of $\$ 1.8$ million outright to $W$. $W$ then annuitizes the $\$ 1.8$ million into an income stream of $\$ 240,000$ per year. There is nothing to prevent $W$ from entering into the annuity contract with $C$ if they can agree. The overall distribution of wealth is much the same as if $H$ had left $W$ a life interest in $\$ 2.4$ million with the remainder to the children but without the adverse tax consequences imposed by the general rule of section 2056(b). If the $\$ 1.8$ million bequest to $W$ is outright, the marital deduction should be available, provided all the subsequent arrangements are entered into voluntarily rather than in accord with preexisting obligations.

Voluntariness is essential. Because of the restriction of section 2056(b)(1)(C), ${ }^{92}$ the executor of $H$ 's estate cannot be instructed to acquire an annuity for $W ; W$ must do so spontaneously. As a result, the annuity pattern may pose a problem for $H$, who may fear that $W$ will spend the money all at once or lose it in bad investments. $H$, therefore, may want to constrain $W$ 's enjoyment of the wealth transferred to her in various ways. The most obvious constraint, however-limiting $W$ 's inheritance to the income-appears to be available only at the cost of losing the marital deduction.

This result suggests an additional purpose of the rule against terminable interests. The rule apparently aims to impose a tax cost on dead hand control as well as to assure at least one tax each generation. In order to make use of the marital deduction, the first spouse to die must either expose the entire value of the property enjoyed by the survivor to subsequent taxation or leave an essentially unrestricted interest.

Dead hand control also carries a tax cost under section 2056(b)(7), ${ }^{83}$ a provision added to the Code by the Economic Re-

92 I.R.C. $\$ 2056(\mathrm{~b})(1)(\mathrm{C})(1982)$, discussed supra note 88 and accompanying text.

s3 I.R.C. $\S 2056$ (b)(7) (1982), the text of which reads in relevant part:

(7) Election with respect to life estate for surviving spouse.-

(A) In general- 
covery Tax Act of $1981^{\text {94 }}$ to allow the marital deduction for "qualified" terminable interests in property. An interest is "qualified" if: (1) the surviving spouse has all the income from the property for life, (2) no person has a power to appoint any part of the property to any person other than the surviving spouse, and (3) the executor elects treatment under section 2056(b)(7). If a life interest is "qualified" the marital deduction lies for the entire value of the property subject to the life interest and not merely for the value of the life interest itself; the entire value of the property must also be included, however, in the estate of the surviving spouse. "Qualified" interests are treated in effect as though the surviving spouse had a fee interest in the underlying property but consumed only the income during life.

Under these rules, if $H$ wants to insure that $W$ will have only an income stream, there may be a tax cost. $H$ 's $\$ 2.4$ million estate can be divided into two trusts, one of $\$ 600,000$ with income to $W$ for her life and remainder to $C$, and the other of $\$ 1.8$ million with the same terms. If the executor elects to treat the larger trust as qualified, a marital deduction of $\$ 1.8$ million will be available, leaving a taxable estate of $\$ 600,000$ (the value of the non-qualified trust). This amount falls within the exemption equivalent and will pass free of tax. As a result of the election, however, $\$ 1.8$ million will be included in W's estate at her death. If $W$ dies in 14 years, there will be a taxable estate of $\$ 1.8$ million at that time, which will pay a tax of roughly $\$ 500,000$. The tax cost of this plan as of

In the case of qualified terminable interest property-

(i) . . . such property shall be treated as passing to the surviving spouse ....

(B) Qualified terminable interest property defined.

For purposes of this paragraph-

(i) In general.

The term "qualified terminable interest property" means property-

(I) which passes from the decedent,

(II) in which the surviving spouse has a qualifying income interest for life, and

(III) to which an election under this paragraph applies.

(ii) Qualifying income interest for life-

The surviving spouse has a qualifying income interest for life if-

(I) the surviving spouse is entitled to all the income from the property, .... and

(II) no person has a power to appoint any part of the property to any person other than the surviving spouse.

Subclause (II) shall not apply to a power exercisable only at or after the death of the surviving spouse.

${ }^{94}$ Economic Recovery Tax Act of 1981, Pub. L. No. 97-34, tit. IV, $\S 403(d)(1), 95$ Stat. 172, 302-03. 
$H$ 's death is approximately $\$ 125,000$ at $10 \%$. From $H$ 's point of view, this $\$ 125,000$ may be regarded as the irreducible tax cost of exercising dead hand control.

\section{The Northeastern Pennsylvania Case}

The imposition of a tax cost on dead hand control may indeed be the general intention of present law, but at least one decided case appears to offer a means of avoiding this choice. In Northeastern Pennsylvania National Bank \& Trust Co. v. United States, ${ }^{95}$ a decedent had provided under his will for certain properties to be placed in trust. The trust property was worth roughly $\$ 69,000$. Under the trust, the surviving wife was to receive $\$ 300$ per month until the couple's youngest child reached eighteen, and $\$ 350$ per month thereafter. If the trust income was insufficient, the corpus could be invaded to make the specified payments; if income exceeded the monthly amount, it was to be accumulated. The surviving wife was also given the power to appoint by will the entire corpus remaining in the trust at her own death. ${ }^{96}$

The Commissioner disallowed any marital deduction for the value of the property in the trust on the ground that it could not be determined that the surviving spouse was entitled for life to all the property from a "specific portion"97 of the trust corpus itself. The Commissioner found support for this position in Treasury Regulations under section $2056(\mathrm{~b})(5),{ }^{98}$ which required that an income interest be expressed as a "fractional or percentile share" of the entire trust income for it to constitute the income from a "specific portion" of an interest in property and therefore to qualify for the marital deduction. The regulations further specified that "if the annual income of the spouse is limited to a specific sum ... the interest is not a deductible interest." agreed with the Commissioner ${ }^{100}$ and held that the marital deduction could be taken for an amount of the corpus of the trust necessary to produce the income stream for the widow "at rate of return available to a trustee under reasonable investment conditions."

${ }^{98} 387$ U.S. 213 (1967).

Id. at 215-16.

${ }^{97}$ See I.R.C. $\$ 2056(\mathrm{~b})(5)$ (1982), quoted in relevant part supra note 91.

9s Treas. Reg. $\$ 20.2056(\mathrm{~b})-5(c)$ (1958).

" Id.

100 Northeastern Pennsylvania, 387 U.S. at 218.

${ }^{101}$ Id. at 224. For a recent case adopting the doctrine of Northeastern Pennsylvania, see Alexander Estate v. Commissioner, Daily Tax Rep., Jan. 11, 1984, at H-1 (T.C. Jan. 5, 1984). In rejecting the Commissioner's denial of the marital deduction for a specific dollar 
Under the doctrine of Northeastern Pennsylvania, if a testamentary trust were funded with $\$ 2.4$ million, if the trustee were instructed to pay the surviving spouse $\$ 240,000$ a year, if a $10 \%$ rate of return were thought reasonable under these circumstances, and if the surviving spouse could appoint the entire corpus of the trust at death, the marital deduction would be available for the full transfer of $\$ 2.4$ million because that amount would constitute the "specific portion" of the trust corpus the income from which equalled the annual stipend. Presumably under this arrangement roughly $\$ 2.4$ million would remain in the trust at the death of the surviving spouse and would be included in her estate by virtue of the power of appointment.

Nothing in the Northeastern Pennsylvania case indicates that the stipend payable to the surviving spouse must be limited to the income derivable from the trust corpus. The principle of the case seems equally applicable where distributions of trust principal in addition to income are necessary to support the stipend. Suppose, for example, that the surviving spouse is to receive $\$ 240,000$ a year for life, but that the trust corpus is only $\$ 1.8$ million. At a $10 \%$ rate of return, some portion of the corpus must be distributed annually to maintain this payment. In effect, the trust corpus must be converted into an annuity of some kind. If the surviving spouse has a life expectancy of 14 years, and $10 \%$ is available under an annuity contract, a prudent course for a trustee would be to fund this bequest by purchasing an annuity. As long as this decision were made unilaterally by the trustee, one could not say that the annuity had been acquired "pursuant to directions of the decedent,"102 but rather that the trustee had been led to this decision by a concern for the prudent management of the trust. Under this

amount of a residuary trust over which the surviving spouse had a power of appointment, the court stated:

If there had not been so much judicial water over the dam on the invalidity of respondent's position, we would listen to the Commissioner's argument more sympathetically, because if the surviving spouse can appoint only the dollar amount of the interest given to her under her deceased spouse's will, only that amount will be taxable in her estate under section 2041 and any increment in value of that interest between her death and the death of her husband will escape estate taxation. However, respondent has made the same argument in every case we have found that has come before the courts, and has lost the argument in every case. We therefore feel that if the statute is to be construed in accordance with respondent's regulation, it is up to Congress to change the language in the statute.

Id. at $\mathrm{H}-1$ to -2 .

${ }^{102}$ I.R.C. $\$ 2056$ (b)(1)(C) (1982). For a discussion of this provision and its consequences in the event that an annuity is purchased for the surviving spouse by the executor pursuant to the decedent's orders, see supra note 88 and accompanying text. 
arrangment, the entire trust corpus would be necessary to fund the stipend, and, according to Northeastern Pennsylvania, the full amount of the trust corpus would therefore qualify for the marital deduction. To be sure, the corpus remaining in the trust at the death of the surviving spouse and subject to her power of appointment would be includable in her estate. If, however, the trust fund had been converted by the executor into an annuity for the surviving spouse, the corpus actually remaining at the death of the surviving spouse would be zero and therefore no further estate tax would be due. There is nothing shocking about this result, since it means only that the full amount committed to the trust for the benefit of the surviving spouse will have been consumed during her lifetime, with nothing left for the next generation. This is much the same result as if the surviving spouse had received an outright bequest of $\$ 1.8$ million and had used it to buy an annuity. The only difference is that the doctrine of Northeastern Pennsylvania appears to allow this result under a trust arrangement created by one spouse for the other, and thereby to allow the marital deduction to coexist with a fairly high degree of dead hand control. ${ }^{103}$

This arrangement is admittedly cumbersome. My purpose is not to recommend it as an estate planning device, but to demonstrate that even within present law as construed by the Supreme Court it is possible to achieve a high degree of dead hand control and still claim the marital deduction. ${ }^{104}$

It is hard to think of any reason for having the availability of the marital deduction turn on a distinction so attenuated as whether the decedent directs the purchase of an annuity or merely makes a disposition that prudently induces the acquisition of one. But that is apparently what present law has come to.

103 Those to whom the remainder of the trust would likely be appointed might complain of a policy by the executor or a trustee to annuitize the fund, leaving nothing to be appointed by the surviving spouse. It is hard to see, however, on what basis they could prevent the trustee from following this policy, provided the surviving spouse acquiesces in it. They can hardly have rights to a corpus which could have been appointed to the Red Cross rather than to them. Should the surviving spouse wish to favor her own heirs, she need only preserve some portion of the stream of trust payments for the next generation.

104 Quite possibly, an arrangement along the lines of Northeastern Pennsylvania could be structured to fit the requirements for "qualified" terminable interests under I.R.C. $\S$ 2056(b)(7) (1982), quoted in relevant part supra note 93 . At a minimum, the trust would have to provide that the surviving spouse would never receive less than the total trust income in any given year and not grant her a power to appoint the corpus during her life. The executor would also have to make the appropriate election. 


\section{Lifetime Gifts of Terminable Interests}

The gift tax provisions contain counterpart rules to those of section $2056^{108}$-codified at sections $2523(\mathrm{~b})$ through (f) ${ }^{108}$ - disallowing the marital deduction for transfers of terminable interests made during life. This prohibition is festooned with exceptions for powers of appointment and "qualified" terminable interests reminiscent of those afflicting the estate tax.

These rules in some form are inevitable as a backstop to the present limitations on the marital deduction at death. Without them, transfers of terminable interests during life would make section 2056(b) a dead letter. Like section 2056, section 2523 does not affect the transfer between spouses of terminable interests in which no other person has a succeeding interest. ${ }^{107}$ One spouse can buy the other an annuity, a car, or a five-ton cake of soap and also claim the marital deduction for the value of the transfer.

Though the effectiveness of section 2056 as it stands at present plainly requires that the parallel section 2523 exist as well, the resulting statutory scheme can lead to unaccountable differences in the tax treatment of certain transfers. For example, there is no counterpart in section 2523 to the rule of section 2056(b)(1)(C), which bars deductibility if the interest in question was purchased for the surviving spouse by the executor upon the order of the decedent. As a consequence, one spouse who is feeling bad and sees the ferry looming can purchase an annuity for the other without jeopardizing the marital deduction, but cannot instruct the executor to do so after the crossing. ${ }^{108}$ Section 2523 is therefore not much of a backstop to the limitations on acquired terminable interests (or to whatever remains of this limitation after Northeast-

${ }^{105}$ I.R.C. $\S 2056(\mathrm{~b})$ (1982), quoted in relevant part supra note 85 .

${ }^{106}$ I.R.C. $\$ 2523(\mathrm{~b})$-(f) (1982). Subsection 2523(b) corresponds to $\S 2056(\mathrm{~b})$, discussed supra at notes 85-94 and accompanying text. Subsection 2523(b) reads in relevant part:

(b) Life estate or other terminable interest-

Where, on the lapse of time, on the occurrence of an event or contingency, or on the failure of an event or contingency to occur, such interest transferred to the spouse will terminate or fail, no deduction [under $\S 2523(\mathrm{a})$ ] shall be allowed with respect to such interest-

(1) if the donor retains in himself . . . an interest in such property, and if by reason of such retention . . . may possess or enjoy any part of such property after such termination or failure of the interest transferred to the donee spouse; or

(2) if the donor immediately after the transfer to the donee spouse has a power to appoint an interest in such property which he can exercise ... in such manner that the appointee may possess or enjoy any part of such property after such termination or failure of the interest transferred to the donee spouse.

${ }^{107}$ See I.R.C. § 2523(b) (1982), quoted in relevant part supra note 106.

${ }^{108}$ See supra notes 88, 102 and accompanying text. 
ern Pennsylvania), but merely adds to the list of things people should think about in their last moments.

\section{E. Simplifying the Marital Deduction}

The limitations on the marital deduction ultimately accomplish little more than to channel marital gifts and bequests into specific patterns and to penalize those who commit various footfaults. Combinations of outright transfers and annuities created during life, or on the pattern of Northeastern Pennsylvania, can achieve results comparable to those of terminable interests without incurring a tax penalty. Because there is little reason to discriminate among what are essentially identical transfers, the restrictions on the marital deduction for terminable interests could simply be eliminated.

The general rule of section $2056(a)^{109}$ would then allow a marital deduction for the value of all interests in property passing to a surviving spouse, whether terminable or not. In addition, decedents could direct their executors or trustees to acquire or create terminable interests for the surviving spouses. Accordingly, $H$ in Example 5 could simply leave $W$ a life interest in $\$ 2.4$ million with remainder to $C$, or instruct the executor to invest $\$ 1.8$ million in an annuity for $W$.

The bluntest way to simplify things-and possibly the best-would be to repeal all of section 2056(b) (which now both limits the marital deduction for terminable interests and creates "qualified" terminable interests). This change would have only a small effect on the tax cost of transferring wealth within families because it takes away from the IRS little more than does the present allowance of the marital deduction for "qualified" terminable interests. ${ }^{110}$ When a "qualified" terminable interest is created under present law, the marital deduction is allowed for the entire value of the property in which the surviving spouse has a life interest (at the cost, to be sure, of the subsequent inclusion of the entire amount in the estate of the surviving spouse). Following the repeal of section $2056(\mathrm{~b})$, however, only the value of the interest in property actually passing to the surviving spouse, i.e., the life interest itself, would be deductible. The additional deferral of tax

109 I.R.C. $\S 2056(\mathrm{a})$ (1982) authorizes the marital deduction.

110 See I.R.C. $\S 2056(\mathrm{~b})(7)$ (1982), discussed supra notes 93-94 and accompanying text. For a discussion of the terminable interest rule reflecting an analysis parallel to that offered here, see Abrams, A Reevaluation of the Terminable Interest Rule, 39 TAX L. REv. 1, 18 (1983). 
resulting under section 2056(b)(7) from a marital deduction larger than the actual value of the interest received by the surviving spouse nearly offsets, in most cases, the subsequent inclusion of the entire underlying property in the estate of the surviving spouse. ${ }^{111}$

A subtler simplification of the law would be to repeal the rules barring the marital deduction for terminable interests, while preserving the option of creating "qualified" terminable interests under present section $2056(\mathrm{~b})(7)$. This change would yield a somewhat more flexible tax regime than would an entire repeal of section 2056(b). The resulting rules would allow a deduction for the entire value of property transferred to a spouse subject to a life interest on condition that its value be included in the estate of the surviving spouse. ${ }^{112}$ A taxpayer could therefore elect to create relatively more income for the surviving spouse at the cost of a larger transfer tax to be borne later by subsequent heirs.

To illustrate, let us return to the example of a $\$ 6$ million estate and assume a surviving spouse with a life expectancy of 7 years. If the whole set of special rules on the marital deduction were simply repealed, a life interest in the entire $\$ 6$ million could be left to the surviving spouse with remainder over to the children. Discounted at $10 \%$, the life interest would be worth roughly $\$ 3$ million, leaving a taxable estate of $\$ 3$ million and a present tax payable of roughly $\$ 1.1$ million. Under the rule of section 2056(b)(7), an election to be "qualified" could be made for this

111 To illustrate, assume an estate of $\$ 6$ million, a discount rate of $10 \%$, and a surviving spouse with a life expectancy of 7 years. In the absence of any special tax regime for terminable interests, the transfer to the surviving spouse of a life interest in the entire $\$ 6$ million with remainder to children, having a present value of $\$ 3$ million, would leave a taxable estate of $\$ 3$ million, entailing a present tax of roughly $\$ 1.1$ million. Under present law, two trusts could be created, one of $\$ 600,000$, with income to surviving spouse and remainder to children, the other containing $\$ 5.4$ million, with similar terms. If an election under I.R.C. $\$$ 2056(b)(7) (1982) were made for the larger trust but not the smaller, no tax would be payable upon the death of the first spouse, since the smaller trust falls within the "zero-bracket" amount. The death of the second spouse will subject the entire $\$ 5.4$ million to estate tax. See supra text following note 94 . The cost of this tax (discounted back 7 years to the time of death of the first spouse at $10 \%$ ) will be $\$ 1.14$ million. Thus, the ultimate difference in tax cost from the repeal of $\S 2056(\mathrm{~b})$ is small. Furthermore, the near equivalence in tax cost just demonstrated arose on the assumption that the same discount rate $(10 \%)$ should be used in valuing the various interests transferred as in assigning a time value to the deferred tax. For reasons adumbrated earlier, see supra notes $41-43$ and accompanying text, one could reasonably apply a different and higher discount rate to the deferral of tax. At a $15 \%$ discount rate, the tax cost of a $\$ 5.4$ million estate in 7 years is $\$ 855,000$. On this basis, the regime of present law is better for the taxpayer than outright repeal of I.R.C. $\S 2056(\mathrm{~b})$ (1982).

${ }^{112}$ See I.R.C. § 2056(b)(7) (1982). 
trust, and no tax would be payable on the death of the first spouse, but a tax on the full $\$ 6$ million in the qualified trust would be payable on average 7 years later. This tax cost discounted back to the time of death of the first spouse at $10 \%$ would be roughly $\$ 1.3$ million. The overall tax cost of electing the "qualified" terminable interest would ultimately be greater by $\$ 200,000$, but this election would leave the surviving spouse with the income from the full $\$ 6$ million, whereas application of the general rule would lead to an earlier tax of $\$ 1.1$ million, which would necessarily reduce the amount available to fund the trust. The surviving spouse would therefore have to make do with the income from $\$ 4.9$ million.

Given the present tax rate structure, the amount of income available to a surviving spouse under either of these two methods would differ significantly only when the estate of the decedent spouse was quite large. There is thus no danger under either method of widows being left destitute by transfer tax costs. ${ }^{113}$ If the only concern were to assure adequate provision for the surviving spouse, the case for retaining "qualified" terminable interests would be less than overwhelming.

There are, however, two further considerations. First, it may be desirable to allow the surviving spouse to appoint the corpus underlying a life interest by will. Without the possibility of "qualified" terminable interests, this pattern would entail additional transfer tax cost. ${ }^{114}$ Second, the present regime for "qualified" interests has the virtue of foreclosing disputes over the value of terminable interests. The rule of section $2056(\mathrm{~b})(7)$ requires only determinations, upon the death of each spouse, of the present value of the entire property underlying a life interest, thereby removing the actuarial element from valuations of terminable interests.

These considerations add up to a reasonable (although not irresistible) case for retaining the present pattern of taxation of "qualified" terminable interests under section 2056(b)(7). The general disallowance of deductions for terminable interests, however-especially terminable interests purchased by the executor-cannot be justified. At a minimum, then, sections 2056(b)(1) through 2056(b)(6) could be dropped from the Code.

11 Where the surviving spouse has a life expectancy of 7 years, there would be no difference in income under either method unless the estate of the first spouse were at least $\$ 1.2$ million, and the difference would be quite small for estates of $\$ 2$ million or less.

114 The corpus of the trust would be included in the surviving spouse's estate, despite the previous inclusion of part of its value (as a remainder not transferred to the surviving spouse) in the estate of the first spouse. 
A possible concern for the Treasury is that an unlimited marital deduction for terminable interests would leave room for manipulation. For example, life interests could be created in favor of spouses known to be ailing and likely to die soon. Because the ailing spouse will die sooner than would statistically be expected, the remainder interest will be undervalued, thereby allowing a part of the value of the transferor's original interest to pass untaxed. One possible countermeasure, which would cut off most abuse, would be to require inclusion in the estate of a surviving spouse of the full amount claimed as a deduction for any terminable interest transferred by the estate of a spouse having died within the preceding three years. ${ }^{115}$

The changes proposed here for the marital deduction at death would of course take along most of the gift tax rules governing terminable interests in their wake. For largely the same reasons as were canvassed above, however, the provision for "qualified" terminable interests in section 2523(f) might be worth preserving.

Viewed broadly, the unlimited marital deduction has the effect of treating spouses as a single taxpayer with a lifetime equal to the survivor's. In this light, the transfer of a life interest from one spouse to the other can be regarded as the retention of a life interest by this notional taxpayer. Present law, however, treats terminable interests transferred between spouses differently from interests retained by single individuals. Under the general rule, transfers of a terminable interest to a spouse are taxed as though the entire property underlying the interest had been transferred to the remainderman. "Qualified" terminable interests, by contrast, are taxed as though the entire property had been retained by the spouses.

Under the system proposed here, only the value of the remainder will attract tax when terminable interests are transferred between spouses. This treatment is the one most consistent with the taxation of retained life interests proposed in Part I of this article. As in the case of retained life interests, this tax regime might tend to favor lifetime transfers by virtue of the tax-base advantage intrinsic in the gift tax rates. For example, the inter vivos transfer of a terminable interest to a spouse with remainder to children would be less costly, for the reasons expounded in Part $I$, than the same transfer made at death. Here also, this possible advantage of life-

115 Compare the proposal preventing undervaluation of deathbed transfers of remainder interests made supra text at note 61 . 
time transfers would be significantly blunted by the inclusion of all gift taxes paid in the taxable estate.

\section{CONCLUSION}

Retained life interests, revocable transfers, and transfers of terminable interests between spouses do not permit the avoidance of tax to an extent that justifies either the complexities induced by the rules limiting these devices or the constraints imposed by these rules on otherwise legitimate methods of estate planning. So long as all transfers of value during life and at death are subject to tax at uniform rates, the advantage of reducing the nominal amount of a transfer taking effect in the future by making it now is essentially offset by the necessity of paying a tax today in dollars of more immediate value.

Present law, however, still does not achieve effective uniformity of rates, because the gift tax itself paid on most lifetime transfers escapes taxation. If the transfer tax base were enlarged to include all gift taxes paid during life-a principle already partly in place under section 2035(c)-much of sections 2036, 2037, 2038, 2044,2056 (b), 2519 , and 2523 could be sent to a well-deserved rest. 